\title{
Malaysian Timber Industry Policy: Achievements, Challenges, and Lessons Learned
}

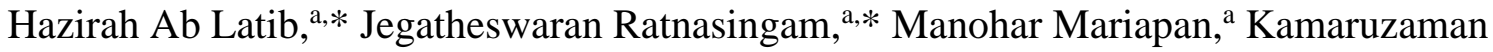 \\ Othman, ${ }^{\mathrm{b}}$ Mohd Afthar Amir, ${ }^{\mathrm{b}}$ Lim Choon Liat, ${ }^{\mathrm{a}}$ Lee Yan Yi, ${ }^{\mathrm{a}}$ Florin Ioras, ${ }^{\mathrm{c}}$ Saeid Reza \\ Farrokhpayam, ${ }^{\mathrm{d}}$ and Natkuncaran Jegatheswaran ${ }^{\mathrm{e}}$
}

\begin{abstract}
The National Timber Industry Plan was the first major dedicated policy framework for the wood products industry in Malaysia. This plan aimed to transform the industry into a high value-added products manufacturer and exporter, with a targeted export value of USD 13 billion in 2020 . Unfortunately, this target was revised downwards in 2017 due to stagnating growth; in 2020, wood products export was valued at USD 5.43 billion. A survey of 914 different wood products manufacturers, involving sawmillers, molding, furniture, and joinery manufacturers, were conducted to examine the constraints faced, and the weaknesses of the policy framework that hampered its intended objectives. The results revealed that the policy framework did not have much impact on transforming the industry, and its growth continued to be fueled by incremental factor inputs, rather than by productivity gains. Uncertainty with the policy framework, especially with addressing raw materials supply and workforce, were highlighted as the two most important constraints faced. In essence, the outcomes suggest that business confidence, associated with industrial growth factors, are the prerequisite for the policy framework to succeed, and if confidence falters, it will adversely affect the targeted outcome of the policy.
\end{abstract}

DOI: 10.15376/biores.17.1.299-315

Keywords: Timber industry; Policy; Sustainable; Raw materials; Workforce; Effectiveness

Contact information: a: University Putra Malaysia, Faculty of Forestry \& Environment, 43400 UPM, Serdang, Selangor, Malaysia; b: Malaysian Timber Industry Board (MTIB), Level 13-17, Menara PGRM, Jalan Pudu Ulu, 56100 Kuala Lumpur, Malaysia; c: Sustainability Centre, Buckingahmshire New University, Queen Alexandra Road, High Wycombe, Buckinghamshire HP11 2JZ, England; d: Department of Wood Science \& Technology, University of Zabol, Zabol, Iran; e: School of Business, University of Wollongong, New South Wales 2522, Australia;

*Corresponding authors: hazirahlatib@gmail.com; jegaratnasingam@yahoo.com

\section{INTRODUCTION}

The Malaysian wood products industry has been transformed from a primary product exporter to a value-added products exporter within a period of three decades. In fact, wood products export occupies the third position after oil palm and rubber exports, within the main commodity exports of the country (Ratnasingam and Muttiah 2020). In 2020, the export of wood products amounted to USD 5.43 billion, with value-added wood products, especially furniture, builders' joinery, and carpentry, and moldings contributing nearly $60 \%$ of this amount (MTIB 2021). Compared to the 1985 period, when the exports of wood products from Malaysia amounted to USD 1.68 billion, with primary products, such as saw-logs, sawn timber, and veneer and plywood, which made up almost $72 \%$ of 
this amount, the present transformation of the export constituents is indeed a success (MTIB 2021). Against such a background, it is no surprise that the wood products industry is often highlighted as an important socio-economic sector, which generated USD 8.39 billion in sales in 2020 (USD 5.43 billion in export earnings, while USD 2.96 billion was generated in domestic sales). Further, it also provides employment to almost 193,000 people, either directly or indirectly, along its supply chain (MTIB 2021).

Despite the wood products industry's sterling performance over the years, much of the growth of the industry has been attributed to a series of favorable government policies, apart from the availability of raw material and workforce at competitive rates (Ratnasingam 2015). The implementation of a series of industrial master plans, which focused on shifting exports of primary products to the manufacture of value-added wood products, was most impactful. To reduce exports of primary wood products, "cess", export levy, and export quota were imposed at various stages of the industry's development, which forced the industry to transform into down-stream manufacturing activities (Ratnasingam and Muttiah 2020). In a study by Teng et al. (2018), it was shown that incremental factor inputs (especially raw materials and workforce) accounted for $30 \%$ of the industry's growth, while favorable policy instruments from 1986 onwards helped spur the rapid transformation of the industry with an aggressive foreign direct investment lead exportoriented industry. The report also suggested that policy instruments (including both fiscal and financial incentives) by the Malaysian government favored industrial growth and accounted for almost $38 \%$ of all growth experienced by the industry over the years. However, it must be emphasized that the growth rate of the wood products industry was not consistent throughout the years, and there is ample evidence to suggest that growth had peaked in 2010 and reached a plateau since (Fig. 1).

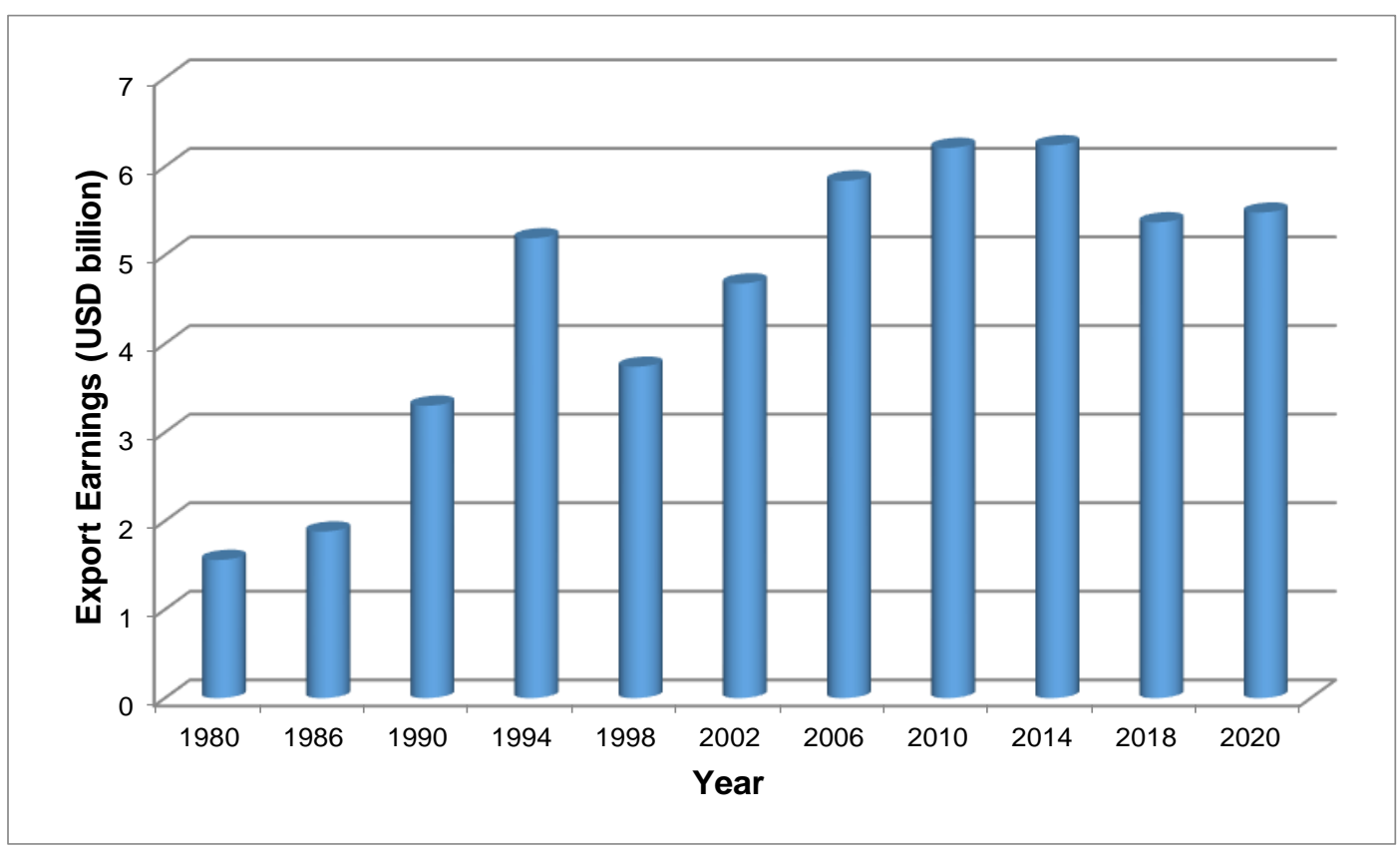

Fig. 1. Export performance of Malaysian wood products (USD)

The question of this stagnating industrial growth rate has never been thoroughly examined. It warrants attention, considering the industry's status as an important socioeconomic sub-sector within the commodity sector of the country. 


\section{POLICY FRAMEWORK FOR THE MALAYSIAN WOOD PRODUCTS INDUSTRY}

In the 1980s, the Malaysian wood products industry was focused on meeting domestic demand, but a large proportion of the primary products produced, particularly saw-logs, sawn timber, and veneer and plywood, were exported predominantly to East Asian countries, particularly to Japan, Taiwan, and South Korea. The government, in recognizing the huge potential for value-added manufacturing of wood products in the country, and to develop the sector into a sizeable socio-economic industry, implemented several measures to restrict exports of primary products. Since 1972, the ten most valuable, commercial wood species were banned from export in the form of saw logs, and a complete ban on all saw logs from Peninsular Malaysia came into effect in 1985 (MTIB 2020). This was followed by the imposition series of export quotas, levy, and cess (which is a tax imposed on exported primary products) in the 1990s, which aimed to encourage further down-stream processing activities. Due to the high demand for Malaysian wood products in the global market, the impact of such restriction in transforming the industry was limited (Ratnasingam 2015).

The major policy framework implemented to boost the wood products industry was a series of Industrial Master Plans, which started in 1986 and ran through 2020. The first Industrial Master Plan (1986 to 1995) (IMP-1) laid down the foundation for the rapid growth of the overall manufacturing sector, including wood products to keep pace with the dynamic changes in the global market. This necessitated the sector to become more competitive and resilient. In line with this, the wood-based sector's emphasis shifted from primary processing to the manufacture of value-added products to improve the captured values of the indigenous and planted forest resources (MTIB 2020). It must be emphasized that the IMP-1 diversified and integrated the wood products industry, leading to more organized value and supply-chain systems, which translated into higher value-addition $(\mathrm{Ng}$ and Thiruchelvam 2012).

The second Industrial Master Plan (IMP-2) (1996 to 2005) further intensified valueadded processing, which saw exports of wood products grow at an annual average rate of 8\% (MPIC 2009). Under the IMP-2, the cluster-based approach towards industrial development was introduced, representing a shift from the traditional industry-based approach. This approach not only emphasized the growth of the manufacturing sector, but also the concomitant growth of the supporting industries that also incorporated the services sector (MITI 1996). The full integration of manufacturing operations through the value chain to enhance industrial linkages and increase productivity and competitiveness was incorporated in the manufacturing-plus strategy advocated in the IMP-2 (Ratnasingam 2015). The goal of the industrial linkages program was to assist Malaysian small and medium enterprises (SMEs) to become competitive manufacturers and suppliers of parts and components and related services to multinational corporations and large companies. Incentive schemes, such as the Pioneer Status with tax exemptions of $100 \%$ on statutory income for 5 years and Investment Tax Allowance of $60 \%$ on qualifying capital expenditure incurred, were offered to qualifying SMEs to entice them to embark on this transformation.

The third Industrial Master Plan (IMP-3) (2006-2020) essentially extended the cluster-based approach to focus on the integrated approach of industrial development (MITI 2017). During the IMP-3, exports of the timber industry were targeted to grow by $6.4 \%$ per annum to achieve the total export value of USD 13 billion by 2020 (MPIC 2009). 
In recognizing the uniqueness of the wood products industry, the government launched the National Timber Industry Plan (NATIP) in 2009 to complement the efforts laid out by the IMP-3. The NATIP was formulated as the guiding framework for the development of the overall wood products industry in Malaysia from 2009 to 2020, which paid special attention to seven key strategies. These include: (1) the transformation of the industry structure into a high-value products manufacturing hub, predominated by competitive SMEs, (2) ensuring a sustainable supply of raw materials, particularly through the establishment of forest plantations, (3) embracing the innovation and technology throughout the industry to boost value-addition, (4) diversifying the market for Malaysian wood products both internationally and domestically, (5) facilitating human capital development for the industry to become less reliant on foreign contract workers, (6) providing the necessary incentives and funding schemes to boost the productivity of the overall industry, and (7) facilitating the growth of Bumiputera (i.e., indigenous people) participation in the wood products industry (NATIP 2009). It was hoped that the NATIP would spearhead the transformation of the wood products industry into a value-added products manufacturing hub of global standard and achieve the target of USD 13 billion in export by the year 2020. It was also meant to be the focal point that outlines the way forward for the industry and determine the appropriate policy directions for critical challenges faced by the industry, to ensure that it remains aligned to the original objective of its projected growth.

\section{Performance of the Wood Products Industry}

In 2020, the total export of wood products from Malaysia was reported to be USD 5.43 billion, which was almost $60 \%$ lower than the initially targeted amount of USD 13 billion under the NATIP. In fact, the government, in realizing the stagnating growth of the wood products industry, decided to revise downwards the target of total exports earmarked in NATIP from USD 13 billion to USD 6.17 billion in 2017. Unfortunately, even this target of USD 6.17 billion was not achieved in 2020, despite the industrial infrastructure and production capacity remaining almost the same throughout the years (Ratnasingam et al. 2018). Because the Covid-19 pandemic had an adverse impact on all sectors throughout the world, evidence from the industry players suggest that its impact has been small on the Malaysian wood products industry, as there was a huge order book in place (Ratnasingam and Muttiah 2020). In this context, the argument that the Covid-19 pandemic may be the main reason for this downtrend is unsustainable.

Although initial reports suggested that inconsistent supply of raw materials together with the limited availability of foreign contract workers were the main industrial growth constraints, it was equally important to assess the overall effectiveness of the NATIP policy framework to invigorate the business environment to spur growth. Table 1 reveals the achievements of the milestones from the various thrust areas as stipulated in NATIP in 2020.

Some evidence on this subject is presented Fig. 2, which reveals the contributions of the various growth factors towards the overall performance of the wood products industry in Malaysia during the period from 1986 to 2019. Although this data is from a study by Ratnasingam and Muttiah (2020), it provided useful insights that confirmed previous narratives that the growth of Malaysian's wood products industry is driven primarily based on cost competitiveness, derived from factor-inputs. 
Table 1. Key Milestones and Achievements of NATIP

\begin{tabular}{|c|c|c|c|}
\hline Milestone & Target Set in 2009 & $\begin{array}{c}\text { Revised Target in } \\
\mathbf{2 0 1 7}\end{array}$ & $\begin{array}{c}\text { Achievement in } \\
\mathbf{2 0 2 0}\end{array}$ \\
\hline $\begin{array}{c}\text { Total Wood Products } \\
\text { Export Value } \\
\text { (USD billion) }\end{array}$ & 13 & 6.17 & 5.43 \\
\hline $\begin{array}{c}\text { Ratio of Value-added } \\
\text { Products: Secondary } \\
\text { and Primary Products }\end{array}$ & $60: 40$ & $55: 45$ & $53: 47$ \\
\hline $\begin{array}{c}\text { Plantation Forests Area } \\
\text { (ha) }\end{array}$ & 375,000 & 150,000 & 137,000 \\
\hline $\begin{array}{c}\text { Original Brand } \\
\text { Manufacturing (OBM) \& } \\
\text { Original Design } \\
\text { Manufacturing (ODM) } \\
\text { Products: Original } \\
\text { Equipment } \\
\text { Manufacturing (OEM) } \\
\text { Products }\end{array}$ & $60: 40$ & $40: 60$ & $30: 70$ \\
\hline $\begin{array}{c}\text { Number of Local Skilled } \\
\text { Workers, Supervisors, } \\
\text { and Managers to be } \\
\text { Trained }\end{array}$ & 10,000 & 4,3000 & 3,800 \\
\hline $\begin{array}{c}\text { Bumiputera } \\
\text { Participation in Export } \\
\text { Market (\%) }\end{array}$ & 5 & 1 & 0.1 \\
\hline
\end{tabular}

Source: Ratnasingam and Muttiah (2020)

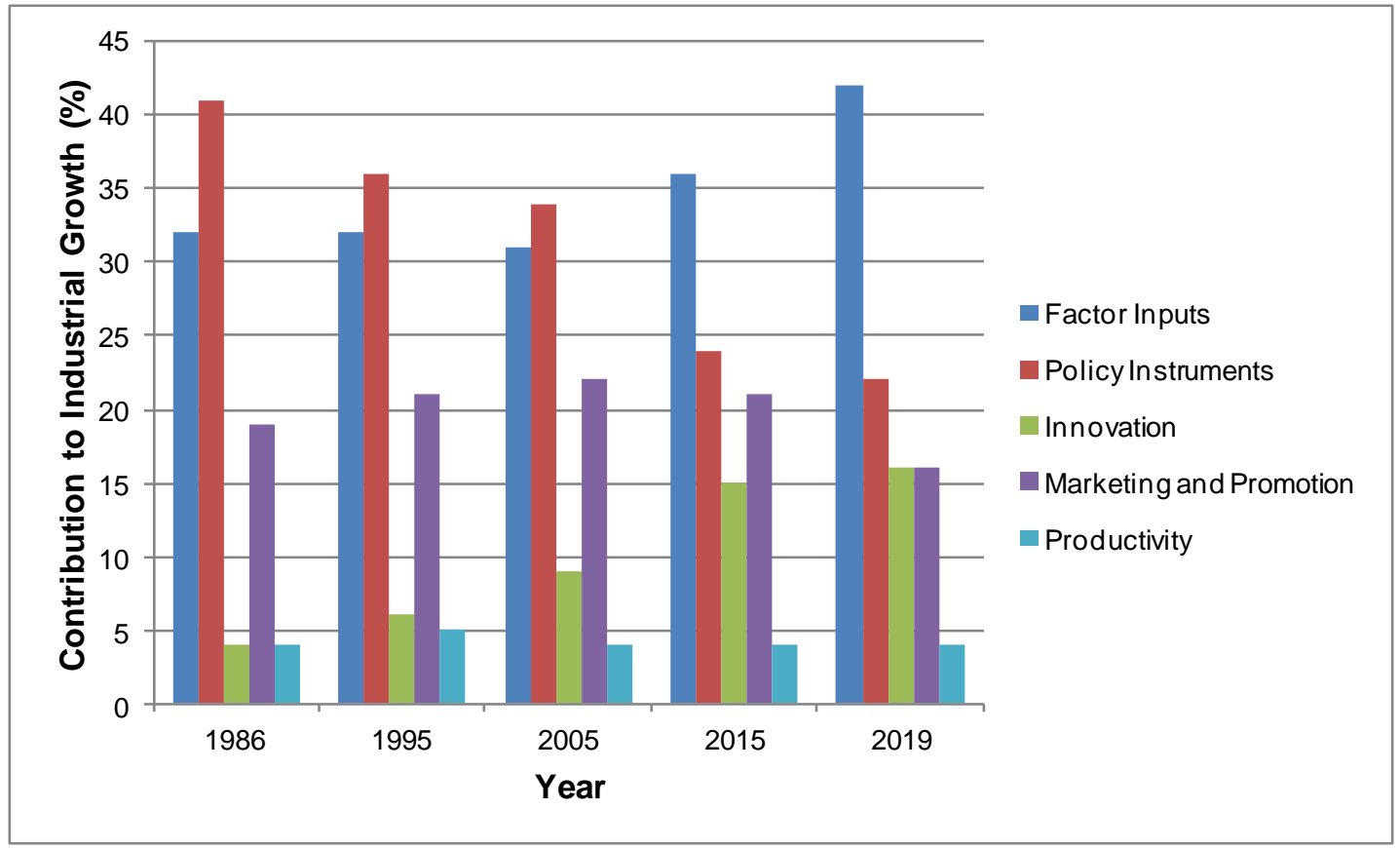

Fig. 2. Relative contribution of the various industrial growth factors in Malaysia

Against the trends shown in Fig. 2, it is apparent that the overall impetus of the policy instruments towards the growth of the wood products industry has not been realized. This is particularly true because innovation and value-addition has remained stagnant, 
while the growth has been driven by incremental inputs, rather than productivity gains. Evidence clearly suggest that factor inputs continue to remain the most important growth factor, clearly emphasizing the fact that growth of the industry is driven primarily by incremental factor inputs (Ratnasingam and Ioras 2009; Niziałek and Podobas 2016). Marketing and promotion activities have been making a constant contribution, while overall productivity has been stagnating. Therefore, it is apparent that although innovation within the industry has been increasing, its rate of increase is somewhat limited, as much of this innovation is derived from diverse materials use, rather than product or technology innovation (Ratnasingam et al. 2019). In earlier studies by Ahmad (2003) and Ratnasingam et al. (2018), it was shown that research and innovative capacities within the industry are limited, which inevitably stifles value-addition, and limits the shift along the product valuechain. Much of the innovations and product diversification in the industry appear to be drawn from external sources, such as suppliers and customers. The argument that the wood products industry has shifted towards original brand manufacturing $(\mathrm{OBM})$ and original design manufacturing (ODM) appears to be premature, based on the stagnating productivity growth depicted in Table 1.

A report by the Malaysian Institute of Economic Research, as quoted by Ratnasingam (2015), argued that transforming the Malaysian wood products industry from its high dependency on factor inputs and conducive policy instruments may be challenging. This argument was put forward on the premise that the wood products industry draws its competitive edge from being a low-cost producer, rather than a high-value-added producer. The report by Ratnasingam and Muttiah (2020) clearly showed that the value of a 40-foot container of wood products, including furniture and joinery, has not increased much over the years, suggesting that price competitiveness is the main driver of growth. Despite increasing raw materials and labor cost, the selling price per unit wood product has shown marginal increments only. Further, the contribution of factor inputs towards industrial growth is well researched and has been extensively documented (Ratnasingam 2015; Teng et al. 2018; Ratnasingam and Muttiah 2020; MTIB 2020). However, the role of the policy framework towards the performance of the Malaysian wood products industry has received little research attention in the past, although its role in transforming the industry and accelerating its growth in the 1980s and 1990s is acknowledged (Teng et al. 2018). Based on such a revelation, it would be worthwhile to evaluate the policy framework from an innovation and value-addition perspective, apart from identifying the weaknesses of the policy framework that did not enhance innovative capacity within the industry. Therefore, a study was conducted to examine the effectiveness and impact of NATIP on the wood products industry, and to identify its weaknesses that hampered sustainable industrial growth. The findings of this study will provide useful insights for future policy framework development, to ensure the attainment of the targeted policy objectives.

\section{EXPERIMENTAL}

\section{Methods}

This study was instituted as an exploratory study using a structured questionnaire (quantitative treatment) to collect data from the population of stakeholders, especially wood products manufacturers. To ensure a fair representation of the various wood products manufacturers in the country, the assistance of the four largest timber trade associations, namely the Malaysian Furniture Council, Malaysian Wood Molding \& Joinery Council, 
Malaysian Wood Industry Association, and the Timber Exporters Association Malaysia were obtained to conduct the sub-sectoral survey. As of 2020, these four associations had a total membership of 2414 companies, and after several discussions with the secretariat of the respective associations, a total of 1080 potential respondents were identified. The potential respondents were wood products manufacturers of furniture, moldings, builders' carpentry \& joinery, and sawn timber, and these companies have been in the business for at least ten years. $84 \%$ of the potential respondents were categorized as small and medium sized enterprises (SMEs), while the remaining 16\% were large-sized enterprises. After contacting each potential respondent, a total of 914 respondents, or $84.6 \%$ of the targeted respondents, agreed to participate in the study. The number of respondents from each of the four associations were comparable.

The survey instrument used in this study was a structured questionnaire, which consisted of five parts. Part I of the questionnaire (with six open ended questions) collected data on the demographic profile of the respondents, while Part II focused on the level of awareness about NATIP among the respondents. The five questions were designed to provide a yes/no answer. Part III focused on assessing the importance placed by ranking each of the seven key strategies laid out in NATIP based on their opinion. Part IV required the respondents to indicate if the 14 constraints faced by the industry were perceived as minor, major, or not a constraint. The respondents were also required to rank the importance of the constraints, giving it a weighted rank for further analysis. Part V of the questionnaire required the respondents to indicate the strategies among the seven key strategies that became the major impediment to NATIP in achieving its objectives, apart from ensuring sustainable growth of the industry.

The questionnaire was designed after consultation with the respective trade associations, manufacturers, policy experts, officials of the government, and after reviewing previous reports by Akbar et al. (2020). Prior to implementation of the survey, the questionnaire was pre-tested among thirty-five manufacturers in the Klang Valley and Melaka, in Malaysia, and based on their feedback and comments, it was validated and improved accordingly. The survey was implemented over a period of 10 months in 2020, through the trade association's offices due to the large number of respondents. The questionnaire was mailed to the target respondents, and a follow up telephone call was made two weeks later to check on the progress with the questionnaire. After four weeks, another call was made reminding respondents to return the filled-up questionnaire using the self-addressed stamped envelope provided.

Due to the large number of respondents, the data from the questionnaires were initially compiled and tabulated using Microsoft Excel software (Microsoft, version 2010, Las Vegas, NV, USA) to facilitate analysis. The analysis of data was performed using the Statistical Package for the Social Sciences (SPSS; IBM, Version 25, New York, NY, USA). Frequency distribution and percentages of the responses were calculated for the tabulated data sets. The relationship between the constraints that affected the respondents' perceptions of the overall success of NATIP were evaluated using the Chi-square $(\chi 2)$ and Pearson Product Moment Correlation (PPMC) (Sudman and Bradburn 1982). The PPMC method was used to establish the correlation between the constraints and the overall success of NATIP, as these constraints were given weighted rank by the respondents, enabling such correlation to be established. It is based on the narrative that some constraints had greater impact compared to the others, although its actual weightage was not measured. To identify the key strategies that became the major impediment to reaching the target set in NATIP, the Binary Logistic Method (BLM) was applied to the data collected from part five of the 
questionnaire (Menard 2002). The BLM measures the relationship between the categorical target variable and one or more independent variables. It is useful for situations in which the outcome for a target variable can have only two possible types (in other words, it is binary). This method makes use of one or more predictor variables that may be either continuous or categorical to predict the target variable classes and is the appropriate test to assess whether NATIP had achieved its objectives or not. This technique helps to identify important factors (Xi) impacting the target variable (Y) and the nature of the relationship between each of these factors and the dependent variable (Menard 2002), which reinforces its applicability to this study. These tests provided useful insights in identifying the primary constraints that shaped the extent to which the wood products industry met its objectives, as stipulated in the NATIP.

\section{RESULTS AND DISCUSSION}

\section{Part I: Profile of Respondents}

Figure $3(a, b)$ reveals the identified scenarios of the respondents who participated in the survey. It is apparent that the respondents were a proportional representation of the various wood products manufacturing sectors operating in the country. Further, a large proportion of the respondents $(84 \%)$ were export-oriented, suggesting the importance of consistent supply of factor inputs, which otherwise, may adversely affect their operations. This scenario was also confirmed by Fajri and Yoshinao (1999) and Ratnasingam et al. (2017), who reported that ensuring a consistent supply of raw materials and workforce play a crucial role in ensuring the sustainable growth of the wood products industry in the country.

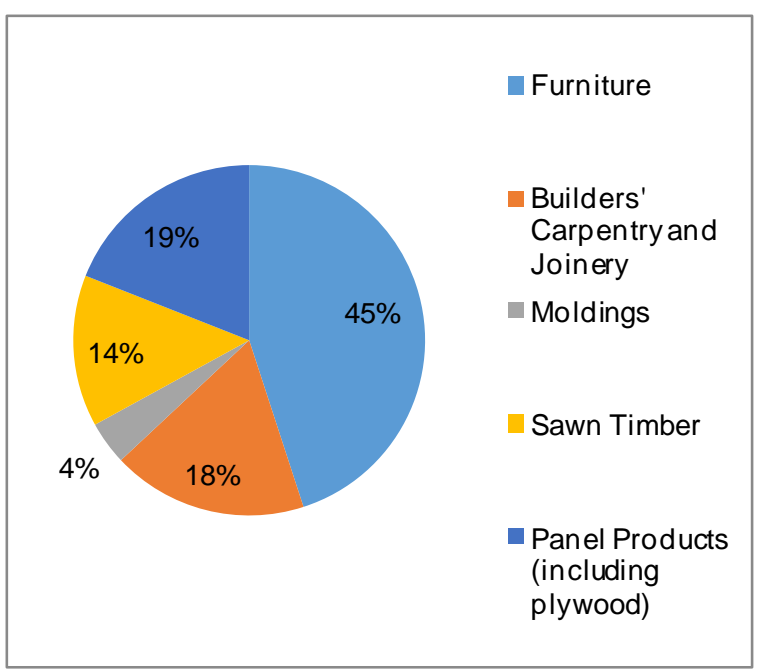

Fig. 3a. Products manufactured by respondents

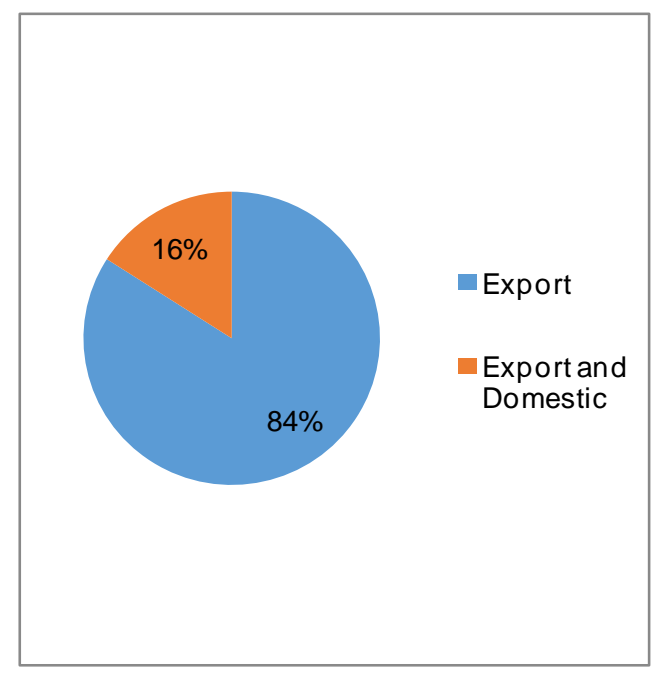

Fig. 3b. Market orientation of respondents

\section{Part II: Level of Awareness of NATIP Among Respondents}

Despite the National Timber Industry Plan being the foremost policy framework for the wood products industry in the country since 2009, the study revealed that the level of awareness of the policy and its key strategies were relatively low (Fig. 4). Although 56\% of the total respondents indicated that they were aware of the NATIP, only $18 \%$ of this 
number were aware of the specific key strategies of the policy framework. A similar observation was made in the report by MITI (2017), who found that the level of awareness, and hence, the ensuing adoption of the key strategies stated in the NATIP, were not encouraging. This shows that despite the policy being formulated, efforts to make it known among the stakeholders have been limited, which in turn somewhat affected its awareness within the industry. In essence, the discord between manufacturers and policymakers is somewhat obvious, and therefore efforts to disseminate the level of information and knowledge to the manufacturers by the relevant agencies, such as the Malaysian Timber Industry Board (MTIB) and Malaysian Timber Council (MTC) must be intensified. It has been shown that in many instances, NATIP was developed in a silo without much in-depth consultation with stakeholders, which may explain its less than desirable outcomes. In this respect, it may be advisable to relook at the roles of these two agencies, to ensure that no duplication in roles takes place. Such duplication is simply a waste of funds due to poor coordination, overlapping activities, and misplaced priorities. This is pertinent, since MTIB was established in 1973 as the sole regulatory and lead agency of the Malaysian timber sector, while MTC, as a company, was established in 1992 to counter the global antitropical timber campaign (Ratnasingam and Muttiah 2020). Conversely, it may be postulated that the effectiveness of NATIP in transforming the wood products industry in the country has also been stifled by the lack of awareness of the policy framework itself among stakeholders, and the lack of follow-up of key strategies by the relevant implementing agencies and its engagement with stakeholders. Perhaps it is high time that the roles of MTIB and MTC is examined again, to ensure that no wasteful duplicating activities are carried out, which has minimal impact on the wood products industry's overall growth. This is pertinent because the Covid-19 pandemic has had a tremendous effect on the country's economy as well as its financial strength.

Being regarded as the lead-industry body, it is timely that MTIB be fully engaged and given resources to undertake needed activities for industrial growth, after consultation and approval by the stakeholders. If such transformations of these agencies are not implemented, there is a risk that these agencies may become irrelevant in terms of industrial development in due course, and be approached only for legislative and regulatory matters.
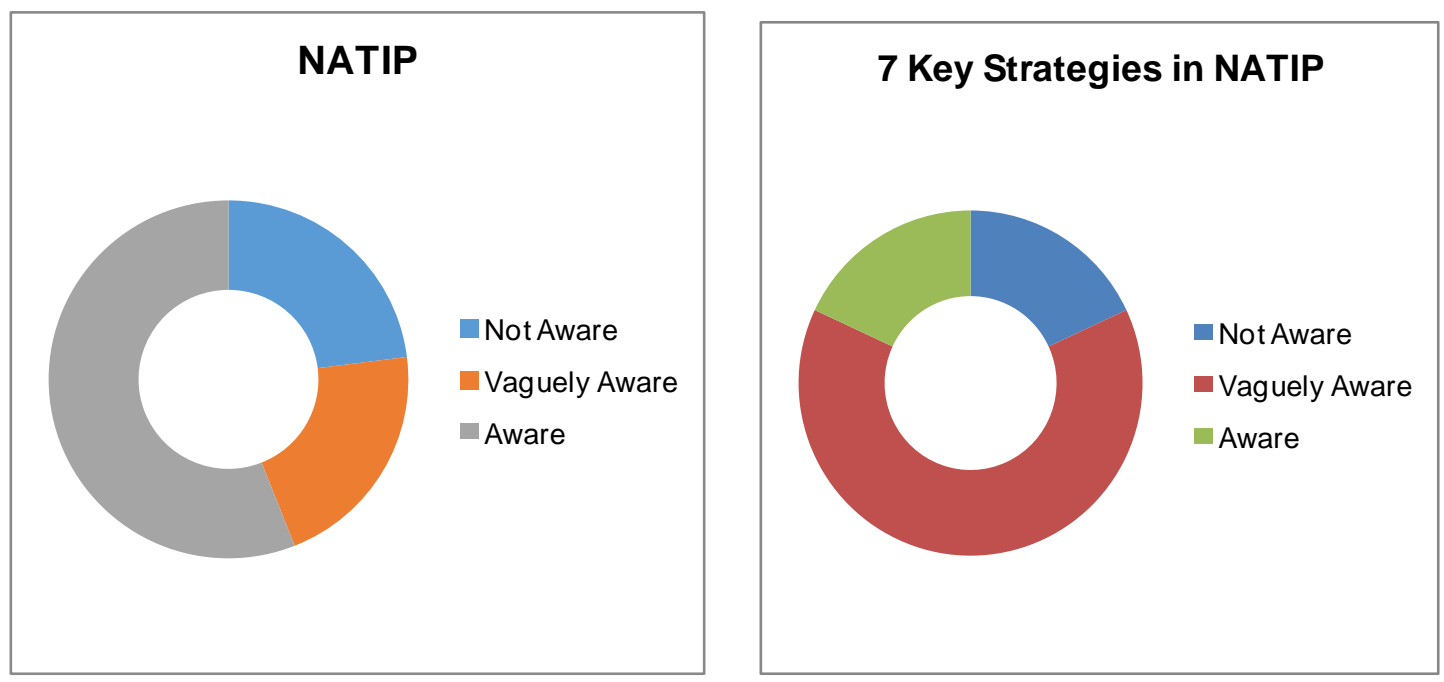

Fig. 4. Identified scenario of respondents for awareness of: (a) NATIP, (b) 7 key strategies of NATIP 


\section{Part III: Perceived Success of NATIP}

Table 2 shows that most respondents perceived NATIP of having limited success in the key strategies stipulated in the policy framework. Only the key strategies related to marketing and promotion and Bumiputera participation were perceived to be a successfully met among the respondents, especially in terms of the numbers of activities undertaken throughout the period. Whether these activities yielded tangible achievements and had an impact on industrial performance was not examined in-depth, but several respondents suggested that the impacts were limited.

On this perspective, an evaluation of the success rate and achievements of NATIP is much warranted, as supported by Merous and Ahmad (2013), who argued that NATIP would need to revisit its key strategies and revisit the related activities to achieve its desired objectives. The reports by Merous and Ahmad (2013) and Ratnasingam and Muttiah (2020) argued that the policy framework did not put into action the necessary strategies and actions plans, especially those related to raw materials supply and workforce development, which inevitably left many of the constraints identified to remain unattended.

Table 2. Respondents' Perception of NATIP

\begin{tabular}{|c|c|c|c|c|}
\hline \multirow{2}{*}{ Statement } & \multicolumn{2}{|c|}{ Frequency } & \multicolumn{2}{|c|}{ Percentage (\%) } \\
\hline & Yes & No & Yes & No \\
\hline \multicolumn{5}{|c|}{ Has NATIP achieved its objectives in the following key strategy areas? } \\
\hline Structure of the Industry & 7 & 91 & 7.14 & 92.86 \\
\hline The Supply of Raw Materials & 4 & 94 & 4.08 & 95.92 \\
\hline Innovation and Technology & 5 & 93 & 5.10 & 94.90 \\
\hline Marketing and Promotion & 28 & 70 & 28.57 & 71.43 \\
\hline Human Capital Development & 4 & 94 & 4.08 & 95.92 \\
\hline Funding and Incentives & 5 & 93 & 5.10 & 94.90 \\
\hline Bumiputera Participation & 51 & 47 & 52.04 & 47.96 \\
\hline $\begin{array}{l}\text { Has NATIP contributed to the growth } \\
\text { and development of the wood-based } \\
\text { industry in Malaysia by increasing } \\
\text { productivity and value-added? }\end{array}$ & 20 & 78 & 20.41 & 79.59 \\
\hline
\end{tabular}

The results also showed that NATIP did not have a positive impact on productivity and value-added growth in the industry, suggesting that the industry has remained trapped as a low-wage sector, relying heavily on low-cost factor inputs to remain competitive (Ratnasingam et al. 2017, 2018). In fact, it has been shown that productivity and innovation growth within the industry has been stagnating since 2015, which indicates an industry that is heavily dependent on cost competitiveness to remain viable. This may also explain why the industry continues to be dependent on low-cost inputs, especially raw materials, and foreign workers (Ratnasingam and Muttiah 2020). A point of concern is that innovation and technology application has stagnated, clearly indicating that the policy framework has run out of options to entice and encourage manufacturers to move towards higher levels of automation and technology options. This point has also been highlighted in the report by Ratnasingam et al. (2019), who argued that the Malaysian wood products industry is highly cost sensitive, and therefore continues to show a high degree of reluctance to adopt automation and technologies, unless sufficient incentives are provided. The National Census of the Malaysian Timber Industry by MTIB (2019) also echoed similar findings, suggesting that a revised policy approach may be necessary to gain the manufacturers' 
attention towards adopting technology and automation, which will inevitably reduce their dependence of foreign contract workers.

\section{Part IV: Constraints that Affected the Achievement of the NATIP Objectives}

The results from the study also identified the four most important constraints facing wood products manufacturers in Malaysia, which were the: (1) lack of long-term plan for human capital development, (2) unavailability of alternative raw materials, (3) increasing production cost, and (4) insufficient workers. Surprisingly, marketing and promotion were not regarded as major problems by the respondents. This is not a surprise, as the Malaysian wood industry is regarded a matured industry, where manufacturers have established customers and a constant market share (Ratnasingam and Muttiah 2020). Further, market diversification is also limited, as most manufacturers operate in the same marketplace. Inevitably, the results also glaringly showed that the Malaysian wood products industry strives to remain competitive by managing its production cost, rather than moving up the value-chain.

In essence, this finding shows that NATIP had a limited effect to invigorate the wood products industry to shift towards higher value-added manufacturing through technology and innovations application. In contrast, without the necessary valueaddition, the wood products industry could not achieve higher out-puts and exports revenues, which in turn necessitated a revision of the initial NATIP target (Ratnasingam et al. 2019).

Table 3. Constraints Faced by Wood Products Manufacturers

\begin{tabular}{|c|c|c|c|}
\hline Constraints & Major & Minor & $\begin{array}{c}\text { Not a } \\
\text { Constraint }\end{array}$ \\
\hline $\begin{array}{c}\text { No long-term plan for human capital } \\
\text { development for the industry }\end{array}$ & $\mathbf{8 4 \%}$ & $3 \%$ & $13 \%$ \\
\hline Uncertainty in raw materials supply & $78 \%$ & $12 \%$ & $10 \%$ \\
\hline Non-availability of alternative raw materials & $\mathbf{8 2 \%}$ & $11 \%$ & $6 \%$ \\
\hline Increasing production cost & $\mathbf{8 4 \%}$ & $16 \%$ & $0 \%$ \\
\hline $\begin{array}{c}\text { Insufficient supply of workers, } \\
\text { particularly foreign workers }\end{array}$ & $\mathbf{8 0 \%}$ & $17 \%$ & $3 \%$ \\
\hline Lack of skilled workers & $70 \%$ & $24 \%$ & $6 \%$ \\
\hline Unclear government policy & $66 \%$ & $20 \%$ & $14 \%$ \\
\hline Over-regulation and bureaucracy & $71 \%$ & $26 \%$ & $3 \%$ \\
\hline $\begin{array}{c}\text { Lack of awareness of funding and financing } \\
\text { opportunities }\end{array}$ & $77 \%$ & $14 \%$ & $9 \%$ \\
\hline Limited technology application & $60 \%$ & $31 \%$ & $9 \%$ \\
\hline $\begin{array}{c}\text { Insignificant value-addition and product design } \\
\text { enhancement }\end{array}$ & $54 \%$ & $39 \%$ & $7 \%$ \\
\hline Market demand & $41 \%$ & $26 \%$ & $33 \%$ \\
\hline Insufficient market promotion & $35 \%$ & $22 \%$ & $43 \%$ \\
\hline Limited participation of Bumiputera in the \\
industry
\end{tabular}

The Chi-square analysis revealed that the important constraints (which was identified based on the respondents' feedback), especially uncertainty in raw materials and labor supply, lack of innovation, and unclear government policies, had negatively impacted NATIP from meeting its objectives (Table 4). Therefore, it is apparent that the uncertainty 
in the supply of raw materials and labor continue to remain challenges faced by the industry, despite numerous initiatives under NATIP, it has not been resolved. Although lack of product innovation is recognized as an important constraint, this constraint could be handled by ensuring a clear policy framework that would facilitate value-added and innovation-driven manufacturing activities, which must be industry-driven. In essence, the role of the government to ensure a conducive business environment with clear policy guidelines is essential to support the continuous growth of the wood products industry, which is recognized as a large socio-economic sector in the country (Reinhardt 2000; Ratnasingam et al. 2018; Samsinar and Firdaus 2019).

Table 4. Chi-square Analysis of Constraints and Its Impact on NATIP's Objectives

\begin{tabular}{|c|c|c|}
\hline Variables & $\mathbf{X}^{\mathbf{2}}$-value & P-value \\
\hline $\begin{array}{c}\text { Uncertainty in Raw } \\
\text { Materials and Labor Supply }\end{array}$ & 26.038 & $0.002^{*}$ \\
\hline $\begin{array}{c}\text { Lack of Marketing and } \\
\text { Promotion }\end{array}$ & 12.615 & 0.326 \\
\hline $\begin{array}{c}\text { Industrial Structure } \\
\text { Lack of Finance and } \\
\text { Funding }\end{array}$ & 21.005 & 0.337 \\
\hline $\begin{array}{c}\text { Unclear Government } \\
\text { Policies }\end{array}$ & 15.476 & 0.674 \\
\hline Lack of Technology Use & 11.073 & $0.041^{*}$ \\
\hline Lack of Innovation & 13.458 & 0.345 \\
\hline
\end{tabular}

*Significant at $\mathrm{P} \leq 0.05$.

The result of the Pearson Product Moment Correlation (PPMC) between the weighted ranked constraints highlighted in Table 5, and the success of NATIP's intended objectives shows a significant correlation $(r=0.461, \mathrm{P}=0.04)$. Therefore, the results suggest that the non-achievements of the targeted export growth as well as other targets laid out in NATIP were accounted by the constraints arising from uncertainty in raw materials and labor supply, coupled with unclear government policies, and the overall lack of product innovation within the industry. These challenges must be overcome sooner than later, as the growth of the wood products industry is driven by incremental input factors, as alluded in many previous studies (Ahmad 2003; $\mathrm{Ng}$ and Thiruchelvam 2012; Ratnasingam 2015).

In the final part of this study, the Binary Logistic Model (BLM) was used to determine the extent to which selected thrusts in NATIP had a major impact on NATIP's overall success. The estimated parameters and the statistical significance levels are shown in Table 5. The dependent variable, which is the targeted growth value of USD 6.17 billion as stated in NATIP, had two categories coded as one or zero, indicating the key strategies' influence on the dependent variable. Out of the seven variables (i.e., key strategies), only two variables, supply of raw materials and human capital development, were positive and statistically significant, which affected the respondent companies perceived impediments to the success of NATIP. This finding has important implications as policy framework can have serious impediments if the follow-up action plan to implement the strategies are lacking, as reported by Amoah et al. (2009) and Kirillova et al. (2019). 
Table 5. Estimated Logit Model for Companies Awareness Towards NATIP

\begin{tabular}{|c|c|c|c|c|}
\hline \multicolumn{7}{|c|}{ Dependent: Awareness of the NATIP } \\
\hline Variable & $\begin{array}{c}\text { Estimated } \\
\text { Coefficient }\end{array}$ & $\begin{array}{c}\text { Standard } \\
\text { Error }\end{array}$ & P-value & Exp(B) \\
\hline Structure of the Industry & 0.732 & 1.441 & 0.611 & 2.079 \\
\hline The Supply of Raw Materials & $0.194^{* *}$ & 1.873 & $0.004^{* * *}$ & 1.214 \\
\hline Innovation and Technology & 0.682 & 4.434 & 0.910 & 1.978 \\
\hline Marketing and Promotion & 0.848 & 0.997 & 0.614 & 2.335 \\
\hline Human Capital Development & $0.096^{* * *}$ & 6.230 & $0.002^{* * *}$ & 1.100 \\
\hline Funding and Incentives & 0.029 & 4.019 & 0.936 & 1.029 \\
\hline Bumiputera Participation & 0.399 & 0.913 & 0.912 & 1.490 \\
\hline Constant & $-3.661^{* * *}$ & 0.857 & 0.000 & 0.026 \\
\hline \multicolumn{7}{|c|}{ Diagnostic Check } \\
\hline -2 Log Likelihood & Nagelkerke R Square & 0.734 \\
\hline $\begin{array}{l}\text { Cox and Snell R } \\
\text { Square }\end{array}$ & Hosmer and Lemeshow & 0.433 \\
\hline *** Statistically significant at 1\% significance level \\
\hline
\end{tabular}

To assess how well the model fits the data, the Hosmer and Lemeshow test was developed, as suggested by Menard (2002). As shown in Table 5, the value for the Homer and Lemeshow test was 0.43 , which was not significant. A non-significant value showed that the model applied was suitable for the data set of this study. In this context, it is apparent that the NATIP, despite being a well-designed policy framework, did not implement action plans to ensure that the key strategies related to the factor-inputs, especially raw materials, and labor, were effectively addressed. Inevitably, the shortcomings became serious limiting factors that necessitated the realignment of NATIP midway the implementation period, with major revision of the targeted export value of wood products in the country (Ahmad 2003; MTIB 2019).

\section{Implications of the Study}

The NATIP was the first major dedicated policy framework for the wood-based industry in Malaysia, and it laid out the objective of reaching an export target of USD 13 billion for the wood products sector by the year 2020. To accomplish this, seven major key strategies were focused upon, with the aim of transforming the industry into a high innovation, technology-oriented wood products industry, while enjoying a sustainable supply of raw materials and workforce. It must be emphasized that six out of the seven key strategies had a direct impact on the success and growth performance of the wood products industry in Malaysia, while the Bumiputera participation strategy are more focused on growing Bumiputera participation in the wood products industry, which is dominated by Chinese entrepreneurs (Ratnasingam and Muttiah 2020). Unfortunately, the target set in NATIP was far-fetched and unattainable, due to stagnating growth of the wood products industry over the last decade. Among the salient reasons for this growth trend were the increasing cost of factor inputs, stagnating productivity, and limited innovation and technology application. Although financing and funding were available, it appeared that most of the funds went into projects to boost the participation of Bumiputera entrepreneurs in the industry, apart from exploiting new export markets for Malaysian wood products. 
Despite numerous initiatives by the government to enable greater growth and higher equity Bumiputera participation in the industry, the actual success recorded has been limited. Nevertheless, such activities will be continued in line with the overall affirmative action as stipulated in New Economic Policy of the country, which aims to ensure higher level of Bumiputera entrepreneurs' participation in the wood products industry. From this perspective, it may be concluded that NATIP has been successful in creating greater awareness of Bumiputera participation in the Malaysian wood products industry, but it had little impact on improving Bumiputera participation and growing their equity in the wood products sector in the country due to weaknesses attributed to the Bumiputera entrepreneurs and the prevailing business ecosystem in the industry (Ratnasingam and Muttiah 2020).

The result of this study reveals that for a policy framework, such as NATIP, to succeed, it is imperative that the constraints faced by stakeholders be addressed to ensure industrial growth is sustained. Without a long-term solution to the uncertainty in raw materials and workforce supply, the Malaysian wood products industry will continue to tread cautiously, which in turn may adversely affect future investments and industry expansion (Ratnasingam and Ioras 2009). Furthermore, the substantial impact suffered by the materials supply-chain during the Covid-19 pandemic revealed the inherent dependency of the industry on factor inputs, when output plummeted to a historic low-level (MTIB 2021). These findings must be seriously considered by policymakers and related agencies, that diminishing confidence among stakeholders due to the perception that the constraints faced are not promptly addressed, will have long term negative impact on the overall growth of the wood products industry in Malaysia. After all, when the industrial growth is fueled by incremental factor inputs, especially raw materials and labor, other growth factors will have minimal impact on the overall industrial growth (Tham et al. 2020). In this context, it is clear that the policy framework for the Malaysian wood products industry needs clear strategic action plans, implemented rigorously, to ensure that the supporting factors are nurtured to contribute to the overall objective of the policy framework (Trømborg et al. 2000).

Despite the NATIP policy framework having good intentions and pragmatic objectives, its achievements have been adversely impacted by poorly executed action plans, that did not positively address the constraints faced by the industry. The wood products industry in Malaysia has grown from a cottage-based industry to an export-oriented industrial sector, and this growth has been fueled by incremental capital inputs, particularly raw materials, and labor. To boost productivity through value-addition, creativity, and technology, the policy framework needs to encompass both the "carrot and stick" approaches to jolt the industry players in this direction. Such an approach is warranted as the prevailing mind-set among many of the manufacturers are rooted in their old cottagebased industry mind-set, reluctant to explore technology and automation, while focusing simply on price competitiveness. It is also clear that when stakeholders lose confidence, they may be reluctant to reinvest into the industry nor expand their business, which will circumvent industrial growth. The eroding confidence among industry players may have been the most important hindrance faced by NATIP in achieving its objectives.

This study clearly underlines the importance of close engagement and consultations between policymakers and stakeholders for successful implementation of industrial policy framework. The targeted outcomes must be supported and facilitated by the necessary factor inputs, so that a friendly and conducive ecosystem is created that would encourage sustainable industrial growth in the highly globalized wood products industry. These 
lessons and recommendations must be taken into consideration for future policy framework development for the Malaysian wood products industry.

\section{CONCLUSIONS}

1. The growth of the Malaysian wood products industry has been driven by incremental factor inputs rather than productivity gains.

2. Constraints related to sustainable supply of raw material and labor continue to hinder industrial growth, and it has been particularly apparent during the Covid-19 pandemic, when supply chains were affected, resulting in a steep decline in outputs.

3. Lack of innovation and increasing production costs are the underlying reasons for wood products manufacturers to focus on cost competitiveness.

4. The Binary Logit Model clearly underlined that the weak strategies and action plans to support the key strategies on raw materials supply and human capital development had significant negative effect on the targeted achievement of NATIP.

\section{ACKNOWLEDGEMENTS}

The assistance of Dr. Saeid Reza Farrokhpayam of the University of Zabol, Iran, with the implementation of the survey and data analysis is much appreciated. The financial assistance from the University Putra Malaysia through the Putra-Grant No. 9469900 to undertake this study is also acknowledged.

\section{REFERENCES CITED}

Ahmad, A. H. (2003). The Participation of the Wood Based Sector in the Malaysian Research and Development Grant Scheme, UPM Press, Serdang, Selangor, Malaysia.

Akbar, F., Khan, R. A., Wadood, F., and Bon, A. T. B. (2020). "Entrepreneurial orientation dimension affects firm performance: A perspective from the Malaysian furniture industry," Entrepreneurial Business and Economics Review 8(4), 157-181. DOI: 10.15678/EBER.2020.080409

Amoah, M., Becker, G., and Nutto, L. (2009). "Effects of log export ban policy and dynamics of global tropical wood markets on the growth of timber industry in Ghana," Journal of Forest Economics 15(3), 167-185. DOI: 10.1016/j.jfe.2008.04.001

Fajri, F., and Yoshinao, M. (1999). "Development of the timber industry and timber trade in Indonesia," Journal of Forest Economics 45(3), 9-15. DOI: 10.20818/jfe.45.3_9

Kirillova, S. S., Borisov, A. N., and Bezrukov, B. A. (2019). "Transformation of the structure of the timber industry complex on the path to new industrialization," IOP Conference Series: Earth Environmental Science 392, Article ID 012061. DOI: 10.1088/1755-1315/392/1/012061

Menard, S. (2002). Applied Logistic Regression Analysis ( $2^{\text {nd }}$ Ed.), Sage Publications, Thousand Oaks, CA, USA. 
Merous, N. H., and Ahmad, I. (2013). "Input factor setback for national timber industry policy," EAS Strategic Options 2013(17), 14-15, (https://econpapers.repec.org/article/epfeasopt/201306.htm), Accessed 20 July 2021.

Malaysian Timber Industry Board (MTIB) (2019). National Census on the Timber Industry, Kuala Lumpur, Malaysia.

Malaysian Timber Industry Board (MTIB) (2020). Annual Report of the Malaysian Wood Industry 2019, Kuala Lumpur, Malaysia.

Malaysian Timber Industry Board (MTIB) (2021). Annual Report of the Malaysian Wood Industry 2020, Kuala Lumpur, Malaysia.

Ministry of International Trade and Industry (MITI) (1996). Performance of Malaysian Timber Sector, MITI Press, Kuala Lumpur, Malaysia.

Ministry of International Trade and Industry (MITI) (2017). Performance of Malaysian Resource-Based Manufacturing Industries, MITI Press, Kuala Lumpur, Malaysia.

Ministry of Plantation Industries and Commodities (MPIC) (2009). Malaysian WoodBased Industry - A Review, Putrajaya, Malaysia.

NATIP (2009). NATIP National Timber Industry Policy 2009-2020, National Timber Policy, Ministry of Plantation Industries and Commodities, Kuala Lumpur, Malaysia.

$\mathrm{Ng}$, B. K., and Thiruchelvam, K. (2012). "The dynamics of innovation in Malaysia's wooden furniture industry: Innovation actors and linkages," Forest Policy and Economics 14(1), 107-118. DOI: 10.1016/j.forpol.2011.08.011

Niziałek, I., and Podobas, I. (2016). "Innovation trends in timber industry form a basis of development in knowledge economy," Annals of Warsaw University of Life Sciences - SGGW Forestry and Wood Technology 95, 270-276.

Ratnasingam, J., and Ioras, F. (2009). "Foreign direct investment (FDI) added value and environmental-friendly practices in furniture manufacturing: The case of Malaysia and Vietnam," International Forestry Review 11(4), 464-474. DOI: 10.1505/ifor.11.4.464

Ratnasingam, J. (2015). The Malaysian Furniture Industry: Unravelling Its Challenges to Growth and Innovation, UPM Press, Serdang, Selangor, Malaysia.

Ratnasingam, J., Ark, C. K., Mohamed, S., Liat, L. C., Ramasamy, G., and Senin, A. L. (2017). "An analysis of labor and capital productivity in the Malaysian timber sector," BioResources 12(1), 1430-1446. DOI: 10.15376/biores.12.1.1430-1446

Ratnasingam, J., Chin, K. A., Latib, H. A., Subramaniam, H., and Khoo, A. (2018). "Innovation in the Malaysian furniture industry: Drivers and challenges," BioResources 13(3), 5254-5270. DOI: 10.15376/biores.13.3.5254-5270

Ratnasingam, J., Ab Latib, H., Yi, L. Y., Liat, L. C., and Khoo, A. (2019). "Extent of automation and the readiness for industry 4.0 among Malaysian furniture manufacturers," BioResources 14(3), 7095-7110. DOI: 10.15376/biores.14.3.70957110

Ratnasingam, J., and Muttiah, N. (2020). Factors Contributing to the Growth of the Malaysian Wood Products Industry - A Critical Analysis, UPM Press, Serdang, Selangor, Malaysia.

Reinhardt, N. (2000). "Back to basics in Malaysia and Thailand: The role of resourcebased exports in their export-led growth," World Development 28(1), 57-77. DOI: 10.1016/S0305-750X(99)00111-4

Samsinar, K. N., and Firdaus, R. B. R. (2019). "Is there a link between environmental expenditure, innovation, and revenue in Malaysian manufacturing industry?," 
Kasetsart Journal of Social Sciences 40(1), 136-141. DOI:

10.34044/j.kjss.2019.40.1.10

Sudman, S., and Bradburn, N. (1982). Asking Questions: A Practical Guide to Questionnaire Design, Jossey-Bass Publishers, San Francisco, CA, USA.

Teng, G. K., Ratnasingam, J., and Thomas, M. (2018). Research on the ASEAN WoodBased Industry - Policy Development and Challenges, UPM Press, Serdang, Selangor, Malaysia.

Tham, L. T., Pretzsch, J., and Darr, D. (2020). "Asian timber value chains-A systematic review and research agenda," Forest Policy and Economics 112, article ID 102116. DOI: 10.1016/j.forpol.2020.102116

Trømborg, E., Buongiorno, J., and Solberg, B. (2000). "The global timber market: Implications of changes in economic growth, timber supply, and technological trends," Forest Policy and Economics 1(1), 53-59. DOI: 10.1016/S13899341(00)00005-8

Article submitted: August 11, 2021; Peer review completed: October 19, 2021; Revised version received and accepted: November 11, 2021; Published: November 17, 2021. DOI: 10.15376/biores.17.1.299-315 